\title{
Mtp-40 and Alpha Antigen Gene Fragment Amplification for the Detection of Mycobacterium tuberculosis in Colombian Clinical Specimens
}

\author{
Rosalba Alfonso $^{+}$, Rosa Elena Romero, Manuel Elkin Patarroyo, Luis Angel Murillo \\ Departamento de Biología Molecular, Fundación Instituto de Inmunología de Colombia, Universidad Nacional de Colombia, \\ Carrera 50 \# 26-00 Bogotá, D. C., Colombia
}

\begin{abstract}
In this study, the use of Mtp-40 and alpha antigen polymerase chain reaction (PCR) amplification fragments for the precise tuberculosis $(T B)$ diagnosis was evaluated. One hundred and ninety two different samples were obtained from 113 patients with suspected TB. Mtp-40 and alpha antigen protein genes were amplified by the PCR technique and compared to both the "gold standard" (culture) test, as well as the clinical parameters (including a clinical record and $X$-ray film exam in 113 patients). Thirty-eight of the 113 patients had a presumptive clinical diagnosis of TB; 74\% being detected by PCR technique, 58\% by culture and $44 \%$ by direct microscopic visualization. We conclude that it is possible to use PCR as a suitable technique for the detection of any mycobacteria by means of the alpha antigen product, or the specific infection of Mycobacterium tuberculosis by means of the mtp-40 gene. This might be a good supporting tool in difficult clinical TB diagnosis and pauci-bacillary cases.
\end{abstract}

Key words: Mycobacterium tuberculosis - alpha antigen - Mtp-40 - polymerase chain reaction

Despite the advances in the handling of infectious diseases and the availability of an effective short course of chemotherapy (DOTS) and the administration of a BCG vaccine, the tubercle bacillus continues to cause more deaths than any other single infectious agent throughout the world (Snider et al. 1994).

In recent years, there has been an increased incidence of tuberculosis (TB) in both developing and industrialized countries, as well as an increase of drug-resistant strains and synergy with the human immunodeficiency virus (HIV). In Colombia the incidence of TB is 19.5 cases for every 100,000 people. A total of 13,000 cases of TB were recorded in 1999 alone (Ministerio de Salud de Colombia 1999). The World Health Organization (WHO) estimates that by the year 2020, nearly one billion people will be newly infected, 200 million people will become sick and 70 million will die from TB if existing controls are not strengthened (WHO/OMS 1998).

Even though a presumptive diagnosis of pulmonary TB is usually established on a clinical basis (the patient's radiological and medical record), a definitive TB case is established by two traditional methods: microscopic examination of acid-fast stained smears and culturing in synthetic media. Although Ziehl-Neelsen staining is a rapid and inexpensive method, it lacks sensitivity and can only detect 10,000 organisms $/ \mathrm{ml}$ or greater in a sample. The "gold standard" diagnosis for TB is the culturing of $M y$ cobacterium tuberculosis. However, it takes a long time to obtain a result in the laboratory, thereby delaying clini-

${ }^{+}$Corresponding author. Fax: +57-1-4815269. Ext. 108. E-mail: rosalba_alfonso@fidic.org.co

Received 15 February 2002

Accepted 21 August 2002 cal and therapeutic decisions (De Wit et al. 1990). In past years, several molecular biology-based techniques have been developed to improve the sensitivity, specificity and speed for M. tuberculosis detection. For example, polymerase chain reaction (PCR) has been used for $M$. tuberculosis diagnosis in different tests and has been shown to be as sensitive as or better than the gold standard test (Del Portillo et al. 1991, Manjunath et al. 1991, De Wit et al. 1992). The PCR technique involves amplifying different genetic elements used as templates within mycobacteria, such as DNA, rRNA (Jonas et al. 1993) or single copy genes encoding 65 or $38 \mathrm{kDa}$ structural proteins (Kaneko et al. 1990, Sjobring et al. 1990, Brisson-Noël et al. 1991). The PCR technique is usually used to amplify variable insertion element sequences, for example IS6110 (De Wit et al. 1990, Eisenach et al. 1990, Thierry et al. 1990). Our group decided to focus its PCR approach on using alpha antigen, abundantly secreted into the culture supernatant of a variety of mycobacterial species (Borremans et al. 1989), and the M. tuberculosis species-specific Mtp-40 fragment. The alpha antigen, also called MPB59 belongs to the 85 complex. This complex is codified by three homologous but distinct structural genes $(\mathrm{Ag} 85 \mathrm{~A}, \mathrm{Ag} 85 \mathrm{~B}$, $\mathrm{Ag} 85 \mathrm{C})$, displaying genetic diversity in species of slow and fast growing mycobacteria (Wiker et al. 1990, Kitaura et al. 1993). The species-specific Mtp-40 gene, identified by our group, has been previously used in several studies as a target element for identification of M. tuberculosis (Del Portillo et al. 1991, Herrera \& Segovia 1996, Faizal et al. 1996, Del Portillo et al. 1996, Marchetti et al. 1998). This fragment encodes a $14 \mathrm{kDa}$ protein belonging to the phospholipase $\mathrm{C}$ family and hybridises only to $M$. tuberculosis DNA but not to DNA from other mycobacterial species, including M. tuberculosis complex species (Parra et al. 1991). Recent studies have shown that the Mtp-40 fragment was not always present in all $M$. tuberculosis clinical isolates (Weil et al. 1996, Vera-Cabrera et al. 1997). 
In the present study, we have evaluated the suitability of the PCR technique in different samples from a group of 113 Colombian patients, amplifying both the Mtp-40 and the alpha antigen genes. The second target gene was used for screening patients who presented TB symptoms; the Mtp-40 gene was used exclusively for specific $M$. tuberculosis identification. When positive results were found by both Mtp- 40 and alpha antigen in the same sample, the presence M. tuberculosis was inferred. A result which was positive for the alpha antigen but negative for Mtp40 , strongly suggests that any mycobacteria, different from M. tuberculosis, was being detected. Nevertheless, since some rare $M$. tuberculosis clinical isolates lack the DNA fragment encoding the Mtp-40, the presence of one of these isolates in the sample cannot be conclusively discarded.

\section{MATERIALS AND METHODS}

Clinical group - The clinical records of a group of 113 patients, ranging from 3 months to 82 years old, with suspected TB were studied retrospectively. The group was composed of in-patient and out-patient cases, variously attending Hospital Santa Clara, Clínica Colsubsidio and Hospital San Juan de Dios, all located in Bogotá, Colombia, between October 1996 and October 1998. Fifty-three percent (60/113) of the patients presented one or various risk factors for TB disease, such as a previous contact history with a diseased patient (23 cases), an HIV positive test (12 cases), a previous tuberculous disease ( 8 cases), malnutrition ( 7 cases), diabetes ( 5 cases), drug abuse ( 4 cases) and Addison's disease (1 patient). The data was double-checked and non-matching laboratory and clinical information was revised and corrected. Contingency tables were drawn up in order to evaluate PCR sensitivity and specificity in comparison with the "gold standard" technique for detection of M. tuberculosis. IBM compatible computers, using statistical software (EpiInfo version 6.04, CDC and Stata 5.0 for Windows, 1997), were used for data analysis.

Clinical samples - A total of 192 samples including sputum, bronchoalveolar lavage (BAL), urine, gastric aspirates, biopsy tissues, pericardic fluid, cerebrospinal fluid (CSF), ascitic fluid and pleural liquid, were obtained from these 113 patients. Samples were taken from patients at the time of a suspected TB diagnosis, with the exception of two patients who were being treated for a period of two months without any clinical improvement. Two containers were used for each sample, one for staining and culturing and the other for chromosomal DNA isolation.

Staining and culturing - All samples were previously de-contaminated according to the Petroff technique (1915); sediment was then suspended in $310 \mathrm{ml}$ sterile distilled water. Ziehl-Neelsen (ZN) staining required $10 \mu \mathrm{l}$ of the suspension and another $100 \mu \mathrm{l}$ were inoculated into each of three slope tubes (Lowenstein Jensen, Stonebrink-G and Middlebrook $7 \mathrm{H} 10$ ) and incubated at $37^{\circ} \mathrm{C}$ for $4-8$ wks. The sterile samples (i.e. CSF, pericardic fluid) were processed without the de-contamination step.

Chromosomal DNA isolation - Fluid samples: a 500 $\mu \mathrm{l}$ aliquot was centrifuged for $10 \mathrm{~min}$ at $14,000 \mathrm{rpm}$ and the pellet resuspended in 10X TE $(1 \mathrm{X} \mathrm{TE}=10 \mathrm{mM}$ Tris- $\mathrm{HCl}$
pH 8.0, plus 1 mM EDTA pH 8.0). Each sample was incubated at $37^{\circ} \mathrm{C}$ with vigorous shaking for $1.5 \mathrm{~h}$ in the presence of lysozyme $(2 \mathrm{mg} / \mathrm{ml})$. The bacterial and cell membranes were lysed by increasing the temperature to $65^{\circ} \mathrm{C}$ and adding sodium dodecyl sulphate and proteinase $\mathrm{K}$ (Sigma, St. Louis, Mo.) to final concentrations of $1 \%$ and $250 \mu \mathrm{g} / \mathrm{ml}$, respectively. After $1.5 \mathrm{~h}$ incubation, the DNA was extracted with chloroform-isoamyl alcohol mix (24:1) and later precipitated with 0.6 volume of isopropanol. The pellet was re-suspended in $1 \mathrm{X} \mathrm{TE}$; sputum samples: one volume of sterile distilled water was added to $200 \mu \mathrm{lali}$ quot of sputum and incubated at $95^{\circ} \mathrm{C}$ for $10 \mathrm{~min}$. The sample was centrifuged at $14,000 \mathrm{rpm}$ for $10 \mathrm{~min}$ and the pellet suspended in 10X TE. The DNA was isolated by the method described above; biopsies: each sample was fragmented using a razor-blade, suspended in 10X TE and processed according to the method already described for fluid samples.

PCR primers - Two sets of primers were used for PCR amplification. Generic primers MT1 (5'-TTCCTGA CCAGCGAGCTGCCG-3') and MT2 (5'-CCCCAGTACT CCCAGCTGTGC-3') were designed to amplify the alpha antigen present in all reported mycobacteria (Matsuo et al. 1990, 1998, Kitaura et al. 1993, Ohara et al. 1993). Species-specific primers PT1 (5'-CGGCAACGCGCCG TCGGTGG-3') and PT2 (5'- CCCCCCACGGCACC GCCGGG-3'), derived from our previously described $M$. tuberculosis Mtp-40 gene fragment, were also designed (Del Portillo et al. 1991). All primers were synthesised by the solid-phase phosphite triester method on a Gene Assembler (Pharmacia, Piscataway, New Jersey, USA) and purified in a 20\% polyacrylamide gel (Maniatis et al. 1989).

PCR amplification - Ten micro-litres from the suspended DNA were used for PCR under standard conditions. All reactions were adjusted to a final $50 \mu \mathrm{l}$ volume, containing: $1 \mathrm{X}$ reaction buffer $(10 \mathrm{mM}$ Tris- $\mathrm{HCl}(\mathrm{pH} 8.3)$, $50 \mathrm{mM} \mathrm{KCl}, 1.5 \mathrm{mM} \mathrm{MgCl} 2$ and $0.001 \%$ gelatin), $1 \mathrm{U}$ Taq DNA polymerase, $0.1 \mathrm{mM}$ of each deoxynucleoside triphosphate and $0.4 \mu \mathrm{M}$ of each primer. A Perkin Elmer thermocycler (Perkin Elmer Cetus) was programmed for 25 amplification cycles as follows: (i) denaturation at $94^{\circ} \mathrm{C}$ for $1 \mathrm{~min}$ and (ii) annealing and extension at $74^{\circ} \mathrm{C}$ for $2 \mathrm{~min}$ for PT primers or $70^{\circ} \mathrm{C}$ for $1 \mathrm{~min}$ for MT primers. The positive PCR control was 100 ng DNA from M. tuberculosis H37Rv (ATCC 27294) and sterile distilled water was used as the negative PCR control. One positive and one negative sputum sample were also included as controls for each procedure.

Dot blot and Southern blot analysis - After amplification, $10 \mu \mathrm{l} \mathrm{PCR}$ mix were boiled for $5 \mathrm{~min}$, cooled immediately on ice and loaded onto a nylon Z-probe membrane (Bio-Rad). The membranes were air-dried and alkaline denatured in $0.4 \mathrm{~N} \mathrm{NaOH}$ and later neutralised in $2 \mathrm{X} \mathrm{SSC}(2 \mathrm{X}$ $\mathrm{SSC}=0.3 \mathrm{M} \mathrm{NaCl}$ plus $0.03 \mathrm{M}$ sodium citrate). For Southern blot analysis, $10 \mu \mathrm{l}$ sample were loaded onto a $1 \%$ agarose gel and alkaline transferred. Hybridizations were performed according to the manufacturer's recommendations (Amersham International, Little Chalfont, Buckinghamshire, England). Probes were obtained from PCR positive controls: 506 bp for MT primers and $396 \mathrm{bp}$ for PT primers. Labeling was performed with $\alpha^{32} \mathrm{P}$-dCTP 
(ICN Pharmaceuticals Inc.) by the Rediprime technique (Amersham International).

Hybridization was done in a solution consisting of 20 $\mathrm{ml}$ for each $100 \mathrm{~cm}^{2}$ membrane containing $1 \mathrm{X}$ SSC, 5X Denhardt's (5X: 0.5 g Ficoll Type 400, 0.5 g Polyvinylpyrrolidone, $0.5 \mathrm{~g}$ BSA Pentax Fraction $\mathrm{V}$ and $\mathrm{H} 2 \mathrm{O}$ to $500 \mathrm{ml}$ ), $0.5 \%$ SDS and $100 \mu \mathrm{g} / \mathrm{ml}$ salmon sperm DNA at $65^{\circ} \mathrm{C}$. After hybridization, membranes were washed twice in $1 \mathrm{X}$ SSC and $0.1 \%$ SDS for $15 \mathrm{~min}$ at $65^{\circ} \mathrm{C}$. They were washed twice again in $0.5 \mathrm{X} \mathrm{SSC}$ and $0.1 \% \mathrm{SDS}$ for $15 \mathrm{~min}$ at $62^{\circ} \mathrm{C}$. Finally, they were washed twice in $0.1 \mathrm{X} \mathrm{SSC}$ and SDS $0.1 \%$ for $15 \mathrm{~min}$ at $60^{\circ} \mathrm{C}$. They were then exposed on Kodak $\mathrm{X}-\mathrm{Omat}$ film, for $15-18 \mathrm{~h}$ at $-70^{\circ} \mathrm{C}$.

\section{RESULTS}

One hundred and thirteen suspected TB patients (having cough and expectoration, fever, weight-loss, anorexia, adenopathies and other suggestive clinical signs and symptoms according to the clinical criteria of the Colombian Ministry of Health) (Ministerio de Salud de Colombia 1995), were enrolled in the present study. For statistical analysis of TB distribution, and taking into consideration that $70 \%$ of the Colombian population is already infected by some type of mycobacteria, patients were divided into 4 age groups: group 1: 0-15 years (59.3\%); group 2: $16-30$ years $(14.2 \%)$; group 3: $31-45$ years $(14.2 \%)$ and group 4: $45-86$ years $(12.4 \%)$. One hundred and ninety two samples (40 sputum, 12 BAL, 7 urine, 102 gastric aspirates, 7 biopsy, 2 pericardic fluid, 18 CSF, 1 ascitic fluid and 3 pleural effusions) were analyzed by conventional methods and by PCR. Gastric aspirates corresponded to more than $50 \%$ of the total, due to the high frequency of pediatric patients in the present study.

In case of multiple specimens taken from a single patient, the result was considered as being positive if at least one of the specimens was positive. However, there were no discrepancies noted between multiple specimens in terms of their smear, PCR, or culture results. As with any diagnostic test, results should be interpreted within the context of clinical findings.

Having the clinical findings and/or response to therapy, 38 patients were shown to be TB positive by clinical diagnosis. Of them, $27(71 \%)$ had pulmonary TB disease and $11(29 \%)$ developed extra-pulmonary TB. The distribution of TB by age groups was as follows: 12 cases in group 1; 7 in group 2; 9 in group 3; and 10 in group 4 . Also, 22 of 29 patients with pulmonary, milliary and pleural TB presented thoracic X-ray study compatible with a TB disease, according to the radiological parameters reported by the Colombian Ministry of Health (Ministerio de Salud de Colombia 1995). PCR amplification and dotblot hybridization, using both Mtp-40 and alpha antigen genes as targets, were performed on every sample analyzed. All positive PCR experiments showed hybridization of both Mtp-40 and alpha antigen genes, suggesting that only M. tuberculosis was present in the specimens analyzed. However, M. tuberculosis co-infection with other mycobacteria cannot be discarded from our results; there have only been two reports of such a case in the literature (Massenkeil 1992, Fernandez \& Chavez 1994), therefore, this interpretation of our results should not be taken as the first choice. Among patients with a positive clinical diagnosis of TB, 15 were found positive by PCR, culture and bacilloscopy tests; 7 were found positive using the PCR and culture tests; 2 were bacilloscopy positive with negative PCR and culture; 6 were only positive by PCR and 8 patients presented negative results by all laboratory methods (Table I). The last group was diagnosed as being tuberculous by clinical findings and had risk factors predisposing them to the disease ( 3 had a positive HIV test, 2 had a history of previous tuberculosis diagnosis, 2 had a history of TB contact and 1 patient was of advanced age).

The Dot Blot hybridization for some samples from different patients and controls, using the radiolabeled Mtp40 PCR fragment as a probe (Fig. 1). Similar results were obtained for alpha antigen (data not shown). Southern blot analysis for alpha antigen and Mtp40-amplified fragments from the same clinical samples (Fig. 2). PCR sensitivity, expressed as a percentage (people having the disease detected by PCR/total number of people tested having the disease), was $100 \%$ [95\% C.I. (Confidence Interval)] and its specificity expressed as a percentage (people without the disease who were negative to the screening test/total number of people tested who did not have the disease) was $93.4 \%$ (95\% C.I.). Positive test PCR predictive value (people having positive diagnosis and positive test/total people with positive test) was $78.6 \%$ and negative test predictive value (people with diagnosis and negative test/total people with negative test) was $100 \%$ (Table II).

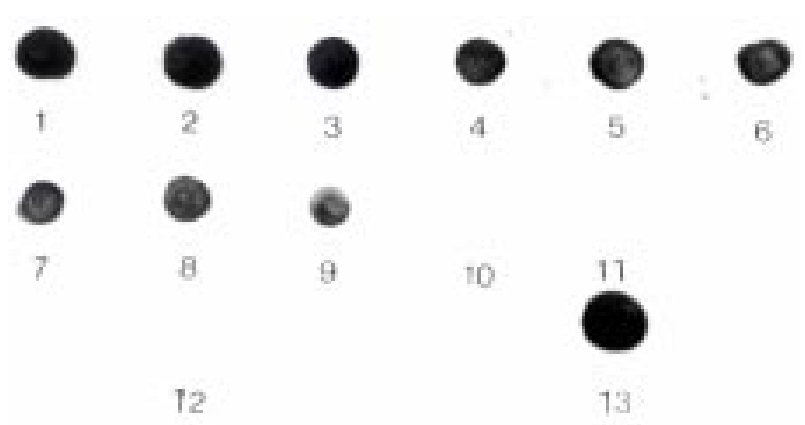

Fig. 1: Dot blot hybridization of Mycobacterium tuberculosis Mtp40 specie-specific fragment, in some clinical samples and controls. 1-3: samples positive culture, bacilloscopy and PCR; 4-6: samples with culture and polymerase chain reaction (PCR) positives; 7-9: samples only with PCR positive; 10-11: samples with all negative laboratory methods; 12: negative chromosomal DNA extraction and PCR controls; 13: PCR Positive control (M. tuberculosis H37Rv DNA). (Dot blot hybridization for the alpha antigen fragment was similar).

\section{DISCUSSION}

Timely identification of the infecting organism is important due to the need for making patient management decisions concerning drug therapy, isolation precautions and prophylaxis. In the case of $M$. tuberculosis infection, early identification is a prime goal for initiating chemotherapy and contact tracing to limit the spread of the dis- 
ease. Until now, molecular biology techniques have offered advantages when compared to traditional methods for TB diagnosis.

In the present study, the distribution of TB cases was slightly similar in the different age groups. The majority of the patients having a final diagnosis of TB presented risk factors, which predisposed them to the disease. It is known that infants and children, who are exposed to adults with pulmonary TB, comprise a group of individuals having high infection risk. Other high-risk groups include people with human immunodeficiency virus (HIV) infection, drug abusers, low-income populations, those held in correctional facilities and people with specific medical risk factors such as diabetes mellitus, chronic renal failure and immunosuppressive disorders, as described in other studies (Committee on Infectious Diseases 1994).

Eight patients with no TB diagnosis by laboratory test presented risk factors predisposing them to the disease. These patients received anti-mycobacterial treatment and their clinical status improved. Two of the patients (who tested positive by $\mathrm{ZN}$ staining and negative for the other detection methods) presented a recurrence of TB after abandoning chemotherapy. It has been reported elsewhere that patients having pulmonary TB may show positive smears with negative sputum cultures at the end of the therapy (WHO 1994-1997, Al-Moamary et al. 1999). Since the introduction of rifampicin, the problem of positive smear with negative culture results has been due to potent anti-microbial activity, but the exact mechanism still remains unclear ( Kaneko et al. 1990, Pierre et al. 1991).

TABLE I

Results of three different detection methods for Mycobacterium tuberculosis diagnosis compared with clinical standards

\begin{tabular}{|c|c|c|c|c|c|c|}
\hline No. & $\begin{array}{l}\text { X-ray } \\
\text { study }\end{array}$ & Samples & $\begin{array}{c}\mathrm{ZN} \\
\text { stain }\end{array}$ & Culture & PCR & $\begin{array}{l}\text { TB clinical } \\
\text { diagnosis }\end{array}$ \\
\hline 1 & $\mathrm{Nd}$ & 1 Urine & + & + & + & Urinary \\
\hline 2 & Com & $1 \mathrm{BAL}$ & + & + & + & Milliary \\
\hline 3 & Com & 3 Sputum, 3 GL & + & + & + & Pulmonary \\
\hline 4 & Com & 2 Sputum & + & + & + & Pulmonary \\
\hline 5 & Com & 1 Sputum, 3 BAL & + & + & + & Pulmonary \\
\hline 6 & No Com & 3 Sputum, 3GL & + & + & + & Pulmonary \\
\hline 7 & $\mathrm{Nd}$ & $1 \mathrm{AA}$ & + & + & + & Peritoneal \\
\hline 8 & No Com & $1 \mathrm{RF}$ & + & + & + & Pericardic \\
\hline 9 & Com & $1 \mathrm{RF}$ & + & + & + & Pericardic \\
\hline 10 & Com & $3 \mathrm{GL}$ & + & + & + & Milliary \\
\hline 11 & Com & 1 Sputum & + & + & + & Pulmonary \\
\hline 12 & Com & 1 Sputum & + & + & + & Pulmonary \\
\hline 13 & Com & 1 Sputum & + & + & + & Pulmonary \\
\hline 14 & Com & 1 Sputum & + & + & + & Pulmonary \\
\hline 15 & Com & 1 Sputum & + & + & + & Milliary \\
\hline 16 & Com & $1 \mathrm{PF}, 1 \mathrm{~PB}$ & - & + & + & Pleural \\
\hline 17 & $\mathrm{Nd}$ & $1 \mathrm{CSF}$ & - & + & + & Meningitis \\
\hline 18 & Com & $2 \mathrm{BB}$ & - & + & + & Spinal \\
\hline 19 & Com & 1 Sputum & - & + & + & Pulmonary \\
\hline 20 & Com & 1 Sputum & - & + & + & Pulmonary \\
\hline 21 & No Com & 1 Sputum & - & + & + & Pulmonary \\
\hline 22 & Com & 1 Sputum & - & + & + & Pulmonary \\
\hline 23 & Com & $2 \mathrm{GL}$ & - & - & + & Pulmonary \\
\hline 24 & Com & $3 \mathrm{GL}$ & - & - & + & Pulmonary \\
\hline 25 & Com & 1 Sputum & - & - & + & Pulmonary \\
\hline 26 & Com & 1 Sputum & - & - & + & Pulmonary \\
\hline 27 & Com & 1 Sputum & - & - & + & Pleural \\
\hline 28 & Com & 1 Sputum & - & - & + & Pulmonary \\
\hline 29 & Com & 1 Sputum & + & - & - & Pulmonary \\
\hline 30 & Com & 1 Sputum & + & - & - & Milliary \\
\hline 31 & No Com & $3 \mathrm{GL}, 1 \mathrm{BAL}$ & - & - & - & Pulmonary \\
\hline 32 & No Com & $3 \mathrm{GL}, 1 \mathrm{BAL}$ & - & - & - & Pulmonary \\
\hline 33 & RUS com & 1 Urine & - & - & - & Urinary \\
\hline 34 & No Com & $3 \mathrm{GL}$ & - & - & - & Pulmonary \\
\hline 35 & No Com & $3 \mathrm{GL}, 1 \mathrm{BAL}$ & - & - & - & Contact children \\
\hline 36 & $\mathrm{Nd}$ & $1 \mathrm{CSF}$ & - & - & - & Meningitis \\
\hline 37 & Com & $1 \mathrm{CSF}$ & - & - & - & Meningitis \\
\hline 38 & No Com & 1 Sputum & - & - & - & Pulmonary \\
\hline
\end{tabular}

TB: tuberculosis; Nd: X-Ray film not determined; Com: X-Ray film TB compatible; No Com: X-Ray film not TB compatible; RUS: renal ultrasound; BAL: bronchoalveolar lavage; GL: gastric lavage; AA: abdominal abscess; PF: pleural fluid; PB: pleural biopsy; CSF: cerebrospinal fluid; MB: pulmonar biopsy; RF: pericardic fluid; BB: bone biopsy; ZN: Ziehl-Neelsen; +: positive test (dot hibridization with both probes); -: negative test 


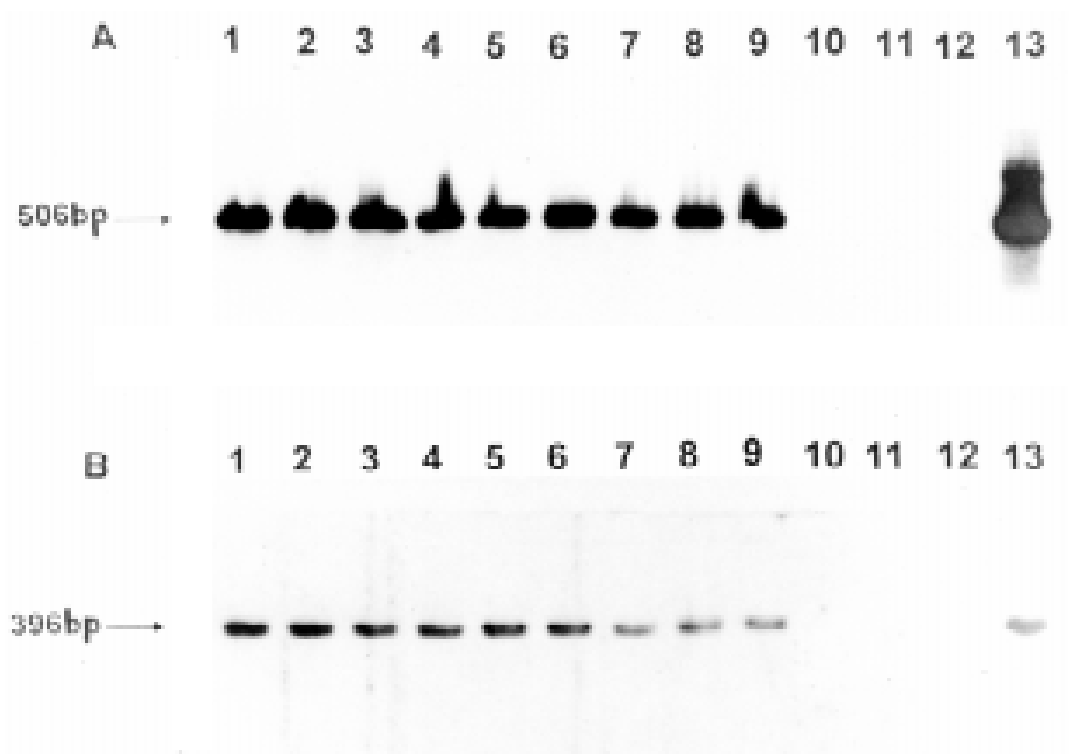

Fig 2: Southern blot hybridization patterns for the same samples shown in Fig. 1, using radiolabeled generic alpha antigen gene (A) and Mtp40 (B) fragments.

TABLE II

Polymerase chain reaction (PCR) sensitivity and specificity

\begin{tabular}{lccr}
\hline Method & Culture (+) & Culture (-) & Total \\
\hline PCR $(+)$ & 22 & 6 & 28 \\
PCR (-) & 0 & 85 & 85 \\
\hline Total & 22 & 91 & 113
\end{tabular}

Sensitivity (95\% C.I.): $100 \%$; specificity (95\% C.I.): $93.4 \%$ (88.3\%-98\%); predictive value of a positive test: $78.6 \%$; predictive value of a negative test: $100 \%$

Our aforementioned two patients also presented a negative PCR test for both Mtp-40 and alpha antigen. Although PCR inhibition by anti-tuberculosis drugs has not been reported to date, several inhibitory factors, including antibiotics, have been described in a standard PCR procedure (Wilson 1997). This fact, in addition to the ongoing rifampicin treatment that these two patients were following suggests that this antibiotic might be responsible for the PCR negative results. Consequently, PCR was not a useful tool for TB diagnosis in the case of these two patients who had had various months of chemotherapy, since false negative results could have been present in the culture and PCR in spite of having had a positive bacilloscopy.

Culturing is considered to be the "gold standard" for confirming a TB diagnosis. However, it is expensive, timeconsuming, the results are only available 4-6 weeks later and it is not very sensitive in pauci-bacillary cases. Taking culture as a reference test for confirming TB diagnosis in this study, PCR sensitivity and specificity was $100 \%$ and $93.4 \%$ respectively. By this method, we were able to detect $M$. tuberculosis in 74\% (28/38) of the cases, being positive to both the mtp-40 and the alpha antigen. This percentage was significantly higher than the results obtained from culture and bacilloscopy: 58\% (22/38) and 44\% (17/38) respectively.

Among the main problems found in routine PCR use as a diagnostic technique is cross-contamination, this can be overcome with the adequate selection of internal controls for both reagents and sample during the set-up process. In spite of the technical difficulties inherent in the methodology and its relatively high price, the cost-benefit balance needs to be addressed, since the improvement in pauci-bacillary detection is clearly enhanced. In our study, PCR was able to detect $15.8 \%$ (6/28) cases more than the culture; this last group corresponding to patients with a difficult diagnose, from whom it was not possible to take good quality samples and who had low bacillary charge (children and elderly people).

The pulmonary form of TB is usually presented $(71 \%$ of cases) and constitutes an epidemiological risk in the population, given the greater dissemination of the bacilli. In this study, group 1 (infants and children) was considerably more important because it represents more than half of the patients where difficult diagnosis occurs due to pauci-bacillary infections and because most of them have a previous history of TB contacts. Our data correlates with previous reports, showing that M. tuberculosis causes the highest incidence of both pulmonary and extra pulmonary TB cases in Colombia (Ministerio de Salud de Colombia 1999).

Previous studies using Mtp-40 in combination with other target genes have shown that its amplification confers a good sensitivity and specificity in the detection of M. tuberculosis in clinical samples (Herrera et al. 1996b, Wei et al. 1999). Another commonly used target gene tested is the insertion sequence IS6110, present in the M. tuberculosis complex. This method lacks the M. tuberculosis strain-specific detection capacity and, because of its de- 
letion in some M. tuberculosis strains, the demonstration of these mycobacteria cannot always be achieved (Yuen et al. 1993, Agasino et al. 1998).

In this study, the utility of two independent amplifications, recognising the presence of M. tuberculosis and related mycobacterial infections in clinical samples, is shown. The combination of these genes increases the TB diagnostic spectrum and confirms that M. tuberculosis is responsible for the infection when both the alpha antigen and Mtp-40 tests are positive. If PCR for alpha antigen is positive and negative for Mtp-40, then the presence of $M$. tuberculosis cannot be discarded. According to our results, all those clinical isolates, positive for M. tuberculosis, analysed in this study contain the Mtp-40 gene.

\section{ACKNOWLEDGMENTS}

To Santiago López and Myriam Neira for analyzing the statistics. To Diana Tovar and Martha Silvera for their technical assistance. To Hospital Santa Clara, Clínica Colsubsidio and the Hospital San Juan de Dios for providing the clinical samples from those patients used in this study. To Manuel Alfonso Patarroyo at our Institute for kindly and patiently reviewing this manuscript.

\section{REFERENCES}

Agasino CB, Ponce de Leon A, Jasmer RM, Small PM 1998. Epidemiology of Mycobacterium tuberculosis strains in San Francisco that do not contain IS6110. Int J Tuberc Lung Dis 2: 518-520.

Al-Moamary MS, Black W, Bessuille E, Elwood RK, Vedal S 1999. The significance of the persistent presence of acidfast bacilli in sputum smears in pulmonary tuberculosis. Chest 116: 726-731.

Borremans M, De Wit L, Volckaert G, Ooms J, De Bruyn J, Huygen C, Van Vooren JP, Steladre M, Verhofstadt R, Content J 1989. Cloning, sequence determination and expression of a 32-kilodalton-protein gene of Mycobacterium tuberculosis. Infect Immun 57: 3123-3130.

Brisson-Noël A, Aznar C, Chureau C, Nguyen S, Pierre C, Bartoli M, Bonete R, Pialoux G, Gicquel B, Garrigue G 1991. Diagnosis of tuberculosis by DNA amplification in clinical practice evaluation. Lancet 338: 364-366.

Committee on Infectious Diseases 1994. Screening for tuberculosis in infants and children. Pediatrics 93: 131-134.

De Wit D, Maartens G, Steyn L 1992. A comparative study of the polymerase chain reaction and conventional procedures for the diagnosis of tuberculous pleural effusion. Tuber Lung Dis 73: 262-267.

De Wit D, Steyn L, Shoemaker S, Sogin M 1990. Direct detection of Mycobacterium tuberculosis in clinical specimens by DNA amplification. J Clin Microbiol 28: 2437-2441.

Del Portillo P, Murillo LA, Patarroyo ME 1991. Amplification of a species-specific DNA fragment of Mycobacterium tuberculosis and its possible use in diagnosis. J Clin Microbiol 29: 2163-2168.

Del Portillo P, Thomas MC, Martínez E, Marañon C, Valladares B, Patarroyo ME, López MC 1996. Multiprimer PCR system for differential identification of Mycobacteria in clinical samples J Clin Microbiol 34: 324-328.

Eisenach KD, Cave MD, Bates JH, Crawford JT 1990. Polymerase chain reaction amplification of a repetitive sequence specific for Mycobacterium tuberculosis. J Infect Dis 161: 977-981.

Faizal M, Jimenez G, Burgos C, Del Portillo P, Romero RE, Patarroyo ME 1996. Diagnosis of cutaneous tuberculosis by polymerase chain reaction using a species-specific gene. Int J Derm 35: 185-188.

Fernandez DF, Chavez F 1994. Mycobacterium scrofulaceum and Mycobacterium tuberculosis coinfection in an AIDS patient. Med Clin (Barc) 102: 799.

Herrera EA, Segovia M 1996. Evaluation of mtp-40 genomic fragment amplification for specific detection of Mycobacterium tuberculosis in clinical specimens. J Clin Microbiol 34: 1108-1113.

Herrera EA, Perez O, Segovia M 1996. Differentiation between Mycobacterium tuberculosis and Mycobacterium bovis by a multiplex-polymerase chain reaction. J Appl Bacteriol 80 : 596-604.

Jonas V, Alden MJ, Curry JI, Kamisango K, Knott CA, Lankford R, Wolfe JM, More DF 1993. Detection and identification of Mycobacterium tuberculosis directly from sputum sediments by amplification of rRNA. J Clin Microbiol 31: 24102416.

Kaneko K, Ondera O, Miyatake T, Tsuji S 1990. Rapid diagnosis of tuberculous meningitis by polymerase chain reaction. Neurology 40: 1617-1618.

Kitaura H, Ohara N, Matsuo K, Tasaka H, Kobayashi K, Yamada T 1993. Cloning, sequencing and expresion of the gene for the alpha antigen from $M$. intracellulare and use of PCR for the rapid identification of $M$. intracellulare. Biochem Biophys Res Comun 169: 1466-1473.

Maniatis T, Fritsch EF, Sambrook J 1989. Molecular Cloning: a Laboratory Manual, 2nd ed., Cold Spring Harbor Laboratory, Cold Spring Harbor, NY, p. 11.23-11.28.

Manjunath N, Shankar P, Rajan L, Bhargava A, Saluja S, Shriniwas 1991. Evaluation of a polymerase chain reaction for the diagnosis of tuberculosis. Tubercle 72: 21-27.

Marchetti G, Gori A, Catozzi L, Vago L, Nebuloni M, Rossi MC, Esposti AD, Ban A, Franzetti F 1998. Evaluation of PCR in detection of Mycobacterium tuberculosis from formalin-fixed, paraffin-embedded tissues: comparison of four amplification assays. J Clin Microbiol 36: 1512-1517.

Massenkeil G, Opravil M, Salfinger M, von Graevenitz A, Luthy R 1992. Disseminated coinfection with Mycobacterium avium complex and Mycobacterium kansdasii in a patient with AIDS and liver abscess. Clin Infect Dis 14: 618-619.

Matsuo K, Yamaguchi R, Yamasaki A, Tasaka H, Terasaka K, Yamada T 1990. Cloning and expression of the gene for the cross-reactive alpha antigen of Mycobacterium kansasii. Infect Immun 58: 550-556.

Matsuo K, Yamaguchi R, Yamasaki A, Tasaka H, Yamada T 1998. Cloning and expression of the Mycobacterium bovis BCG gene for extracellular alpha antigen. J Bacteriol 170: 3847-3854.

Ministerio de Salud de Colombia 1995. Tuberculosis, Prevención y Control. Manual de Normas, Bogotá, p. 55-56.

Ministerio de Salud de Colombia 1999. Epidemiología de la tuberculosis en Colombia. Bol Epidemiol 4: 81-92.

Ohara N, Matsuo K, Yamaguchi R, Yamasaki A, Tasaka H, Yamada T 1993. Cloning and sequencing of the gene for alpha antigen from M. avium and mapping of B cell epitopes. Infect Immun 61: 1173-1179.

Parra CA, Londoño LP, Del Portillo P, Patarroyo ME 1991. Isolation, characterization and molecular cloning of a specific Mycobacterium tuberculosis antigen gene. Identification of a species-specific sequence. Infect Immun 59: 34113417.

Petroff SA 1915. A new and rapid method for isolation and cultivation of tubercle bacilli directly from the sputum and feces. J Exp Med 21: 38-42.

Pierre C, Lecossier D, Boussougant Y, Bocart D, Joly V, Yeni P, 
Hance AJ 1991. Use of reamplification protocol improves the sensitivity of detection of Mycobacterium tuberculosis in clinical samples by amplification of DNA. J Clin Microbiol 29: 712-717.

Sjobring U, Mecklenburg M, Andersen AB, Miorner H 1990. Polymerase chain reaction for detection of Mycobacterium tuberculosis. J Clin Microbiol 28: 2200-2204.

Snider Jr DE, Raviglione M, Kochi AM 1994. Tuberculosis: Pathogenesis, Protection and Control, Bloom BR, Am Soc Microbiol, Washington D.C., p. 2-11.

Thierry D, Brisson-Noel A, Vincent-Levy-Frebault V, Nguyen S, Guesdon JL, Gicquel B 1990. Characterization of a Mycobacterium tuberculosis insertion sequence, IS6110 and its application in diagnosis. J Clin Microbiol 28: 2668-2673.

Vera-Cabrera L, Howard ST, Laszlo A, Johnson WM 1997. Analysis of genetic polymorphism in the phospholipase region of Mycobacterium tuberculosis. J Clin Microbiol 35: 1190-1195.

Wei CY, Lee CN, Chu CH, Hwang JJ, Lee CP 1999. Determination of the sensitivity and specificity of PCR assay using different target DNAs for the detection of Mycobacterium tuberculosis. Kao Hsiung I Hsueh Ko Hsueh Tsa Chih 15: 396-405.

Weil A, Plikaytis BB, Butler WR, Wodley CL, Shinnick TM 1996. The mtp-40 gene is not present in all strains of Mycobacterium tuberculosis. J Clin Microbiol 34: 2309-2311.

Wiker HG, Sletten K, Nagai S, Harboe M 1990. Evidence of three separate genes encoding the proteins of the Mycobacterial Antigen 85 Complex. Infect Immun 58: 272-274.

Wilson IG 1997. Inhibition and facilitation of nucleid acid amplification. Appl Environ Microbiol 63: 3741-3751.

WHO-Worl Health Organization 1994-1997. Anti-tuberculosis drug resistance in the world. The WHO/IUATLD Global Projet on Anti-tuberculosis Drug Resistance Surveillance, Global Tuberculosis Programme, Geneva.

WHO/OMS 1998. Tuberculosis. Fact sheet 104: 1-5.

Yuen LK, Ross BC, Jackson KM, Dwyer B 1993. Characterization of Mycobacterium tuberculosis strains from Vietnamese patients by Southern blot hybridization. J Clin Microbiol 31: 1615-1618. 